\title{
Groundwater renewable resources in karst areas, the case of the Kleśnica River basin (Sudety Mountains, Poland)
}

\author{
Tomasz Olichwer*, Adrian Otrębski
}

Tomasz Olichwer: Wroclaw University, Institute of Geological Sciences, pl. M. Borna 9, 50-204 Wroclaw, Poland

Adrian Otrębski: ARCADIS Poland, ul. Jana Długosza 60, 51-162 Wrocław, Poland

Record

Hydrometric measurements of the low flow of the Kleśnica River show high groundwater runoff, which is typical for karst areas.

Abstract

The karst-fractured medium constitutes a considerable groundwater capacity, as shown on the example of the Kleśnica River basin. The paleozoic crystalline limestones in the research area are good collectors of the groundwater. The Kleśnica River basin, one of the largest crystalline limestone lens, is situated in the Sudety Mountains. Groundwater renewable resources were distinguished with the use of hydrological methods, on the basis of hydrometric measurements of the flow discharge of the Kleśnica River during the low-flow period (2009-2010). The mean module of the groundwater runoff equals $20.79 \mathrm{dm}^{3} / \mathrm{s}^{*} \mathrm{~km}^{2}$, and includes the study of the river catchments areas with extremely high groundwater runoff. The groundwater renewable resources in the Kleśnica River basin are almost twice higher than in the neighbouring river basins (the Kamienica and Morawka River basins), in which there are no significant outcrops of carbonate rocks. These considerable renewable resources also provide a high runoff in the spring, $7.98 \mathrm{dm}^{3} / \mathrm{s}^{*} \mathrm{~km}^{2}$. The high values of the runoffs indicate, that the groundwater is coming from the regional circulation system and, on a smaller scale, from the local system. The groundwater from both systems flows into the fractured system through the karst of carbonate massif rocks and their weathering fringes.

\section{Introduction}

According to the definition, the hydrogeological medium is made of rocks with open spaces, which are a fixed component of the hydrogeological environment (Bocheńska et al., 2002a) and can be characterised as simple (e.g. a porous medium), or complicated (e.g. a fractured-karst medium hydrogeological space). In nature, the following mediums are observed: porous, fractured-porous, fractured, karst-fractured and fractured-karst-porous. In addition, hydrogeological medium depending on the physical properties may be continuous, discontinuous and isotropic or anisotropic. An example of a discontinuous and anisotropic hydrogeological medium is the karst-fractured one represented by the Kleśnica River basin.

The karst system can be divided as follows (Gilli et al., 2013):

- the epikarst, decompressed zone within which dissolution has acted in all directions to enlarge discontinuities. The epikarst is less anisotropic than the rest of the unsaturated zone. It is a highly permeable environment,

- the unsaturated zone, in the strictest sense, not very open, cut through by tectonic accidents. Sometimes perennial outflows are observed,

- the saturated zone, characterised by micro-fissured blocks, large drainage passageways and the annex to the drain systems.
Keywords

karst areas $\cdot$ groundwater runoff $\cdot$ Śnieżnik Massif

Received: 15 September 2015 Accepted: 16 January 2016

Additionally, the karst hydrosystem is characterised by:

1. High-capacity, low-transmissivity micro-fissured blocks (Motyka, 1998).

2. Lower capacity and high transmissivity of drainages and high capacity of the annex to the drain system, poorly connected to the main drain (Gilli et al., 2013).

In the hydrogeology of mountain areas, the karst-fractured medium is very important for the accumulation of groundwater. In the mountains of karst aquifers, the accumulation of groundwater resources is greater in relation to other hydrogeological mediums (Ciężkowski, 1989; Ciężkowski et al., 1997; Bocheńska et al., 2002b; Olichwer, 2002). A feature of karst areas is the occurrence of highly effective springs. The examples are the biggest springs in the world and Europe, that is, Wakulla Spring (USA, $\mathrm{Q}=55 \mathrm{~m}^{3} / \mathrm{s}$ ) (Schmidt et al., 1998) and La Sorgue (France, $\mathrm{Q}=$ $23 \mathrm{~m}^{3} / \mathrm{s}$ ) (Gilli et al., 2013). In Poland, too, the karst springs are considered the most effective (Ice Spring, $\mathrm{Q}=1 \mathrm{~m}^{3} / \mathrm{s}$, Tatry Mountains) (Małecka, 1997).

In the Sudety Mountains, two locations of carbonate rocks occurrence deserve attention, that is, the Kłodzko Region and the Kaczawskie Mountains. In both areas, there are karst springs with discharges up to several dozen $\mathrm{dm}^{3} / \mathrm{s}$. In the Wojcieszów area, $40 \%$ of spring runoff came from karst water, while in the Krowiarki area, the share of karst groundwater was up to $80 \%$ 
Table 1. Groundwater runoff characteristic of Kleśnica River basin.

\begin{tabular}{c|c|c|c}
\hline Autor & $\begin{array}{c}\text { H. Kryza } \\
\text { (1988) }\end{array}$ & $\begin{array}{c}\text { R. Tarka } \\
\text { (1997) }\end{array}$ & $\begin{array}{c}\text { H. Kryza, J. Kozłowski } \\
\text { (1998) }\end{array}$ \\
\hline Range of data & $1974-1981$ & $1976-1980$ & $1993-1994$ \\
\hline $\mathrm{H}_{\mathrm{g}}\left[\mathrm{dm}^{3} / \mathrm{s}^{*} \mathrm{~km}^{2}\right]$ & 20.3 & $19.3-21.9$ & $9.99-25.61$ \\
\hline $\mathrm{H}_{\mathrm{p}}[\mathrm{mm}]$ & 642 & $608.6-690.6$ & $315-801.6$ \\
\hline
\end{tabular}

$\mathrm{H}_{\mathrm{p}}$ - groundwater runoff coefficient

(Romanowskie spring) (Bocheńska et al., 2002b). The total volume of groundwater in the reservoir rocks drained by karst spring was estimated at $8.54 \times 10^{8} \mathrm{~m}^{3}$ in the area of Kaczawskie Mountains and $3.47 \times 10^{9} \mathrm{~m}^{3}$ in the Krowiarki (Kłodzko Region). The main recharge zones of sudetic karst river basins are located in the upper parts of the hills and consist of crystalline limestones, while the additional recharge comes from the surface water and waters of fractured crystalline rocks, surrounding limestone (Bocheńska et al., 2002b).

The Kleśnica River basin, located in the Śnieżnik Massif (Sudety Mountains), was selected for the detailed characteristic of the groundwater renewable resources of karst areas. The study area was the complicated hydrogeological structure characterised by the occurrence of extensive karst formations, represented by crystalline limestones. Groundwater occurs mainly in marble as inserts and lenses in mica schists and paragneisses. The studies of the groundwater renewable resources (identified with groundwater runoff) of the Kleśnica River basin were realized mainly by Kryza (1988), Ciężkowski (1989), Bieroński (1989), Tarka (1997), Kryza \& Kozłowski (1998). According to Kryza`s researches and measurements, the groundwater runoff, based on the mean low river flows at the Kleśnica River estuary and expressed as the groundwater runoff module $\mathrm{H}_{\mathrm{g}}\left(\mathrm{dm}^{3} / \mathrm{s}^{*} \mathrm{~km}^{2}\right)$, ranged from 16 to 26.7 (mean 20.3) (Kryza, 1988). These results allow for the location of the runoff from the research area to an VIIIth class (more than $10 \mathrm{dm}^{3} / \mathrm{s}^{*} \mathrm{~km}^{2}$ ), which is typical for the catchments of extremely high groundwater runoff module (Krasny \& Kneżek, 1977).

Similar values of $H_{g}$ were also calculated by Tarka (1997) with the use of the hydrograph separation, Wundt methods $\left(\mathrm{H}_{\mathrm{g}}=\right.$ $\left.21.9 \mathrm{dm}^{3} / \mathrm{s}^{*} \mathrm{~km}^{2}\right)$, and the Kille method $\left(\mathrm{H}_{\mathrm{g}}=19.3 \mathrm{dm}^{3} / \mathrm{s}^{*} \mathrm{~km}^{2}\right)(\mathrm{Ta}-$ ble 1). Seasonal changes in groundwater runoff were investigated by Kryza \& Kozłowski (1998). River flow measurements were carried out during the four seasons: spring, summer, autumn (1993) and winter (1994). The results of the measurements showed a fall in the groundwater runoff module in the range of $9.99 \mathrm{dm}^{3} / \mathrm{s}^{*} \mathrm{~km}^{2}$ (autumn) to $25.61 \mathrm{dm}^{3} / \mathrm{s}^{*} \mathrm{~km}^{2}$ (spring).

\subsection{Research Area}

The Kleśnica River basin $\left(14.7 \mathrm{~km}^{2}\right)$ representing the karst-fractured medium was chosen to the resource characteristic. The study area is located in the northern part of the Śnieżnik Massif
(Figure 1). According to the hydrogeological regionalisation of Poland, the described area belongs to the Śnieżnicko-Złotostocki subregion and manifests there hydrodynamic conditions typical for a hydrogeological massif. Groundwater occurs in the Quaternary deposits and Paleozoic crystalline rocks. This area is a complicated water-bearing structure with complex and diverse hydrogeological conditions. Groundwater is mainly supplied by precipitation, which infiltrates the most uplifted parts of the unit and then supplies successively the weathering cover zone, the weathering and shallow fractures zone as well as the deep faults zone. The research area consisted of early Paleozoic metamorphic rocks (mica schists, gneisses, amphibolites). Also almost continuous weathering cover up to $3 \mathrm{~m}$ thick occurs in the study area. A very important element of the river catchment is the occurrence of large crystalline limestone lenses within the mica schists and paragneisses (Don et al., 1990). These rocks together make up the karst-fractured zone with thickness of up to $1 \mathrm{~km}$. Crystalline limestones are characterised by a large system of fractures and dislocation zones, and, on this basis, represent a highly developed karst phenomena.

Kryza (1988) distinguished four systems of the Śnieżnik Massif groundwater circulation:

3. Regional, with the longest range; water infiltrates into the massif up to a depth of at least $1.5 \mathrm{~km}$ using the deep faults.

4. Regional, on a smaller scale, whose drainage base is the Biała Lądecka River and the upper Nysa Kłodzka River. The water is infiltrates into the massif in a way similar to the previous case, but to depth of $800 \mathrm{~m}$.

5. Local; it includes groundwater within the fractured massif and weathering covers to a depth of $20 \mathrm{~m}$. Water runoff takes place by natural outflows up to the surface and inflows in the river bed to the Kleśnica River and inflowing streams.

6. Local, with a very limited range, which occurs for short periods of time and is drained by periodic springs and outflows.

Kryza (1988) also proposed the division of groundwater occurrence environment: the weathering cover zone, the fractured massif zone, the deep faults zone and the fractured-karst carbonate rocks zone.

The inside study area is located mainly in the region lens of crystalline limestones (Figure 2), in which the bear cave system developed, while the neighbouring Kamienica River basin was occupied by a large outcrops of erlans. In the Kleśnica River basin, due to the thin weathering cover, the rainwater easily migrates deep into the massif, where, using fractures, interlayer spaces and karst void, dilutes and dissolves the rock and thus changes and enriches their chemical composition (Mroczkowska, 1983). Pulina (1970) had already observed an active karst zone in the Kleśnica River basin in 1962. In autumn, during a low water flow, the Kleśnica River disappears completely on the section 840$760 \mathrm{~m}$ a.s.I. A further research conducted by Pulina, Kryza, Rehak, Ciężkowski in the 70-80th (Pulina, 1970; Ciężkowski et al., 1986; Kryza, 1988) confirmed the existence of a karst system that would 


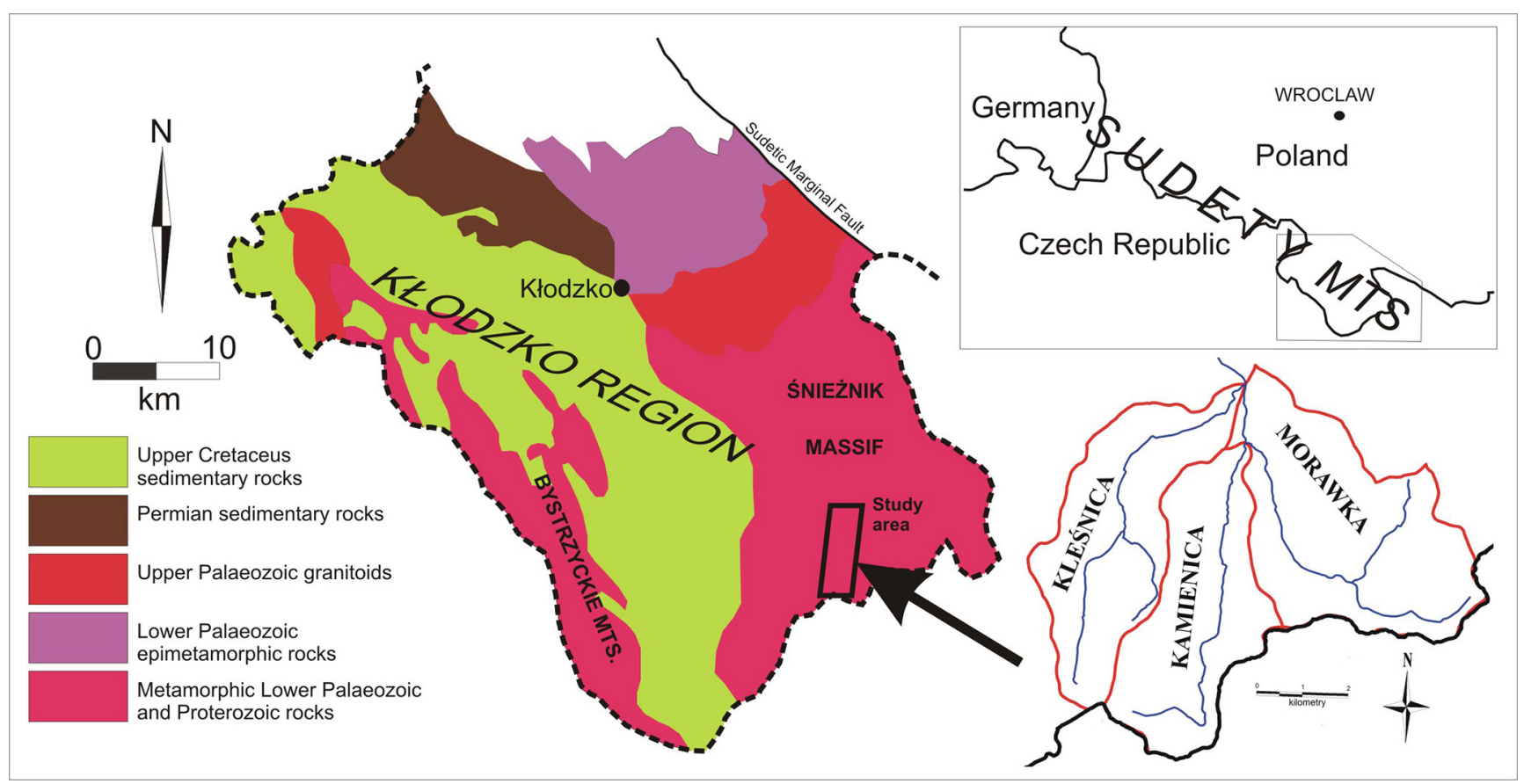

Figure 1. The map of the research area.

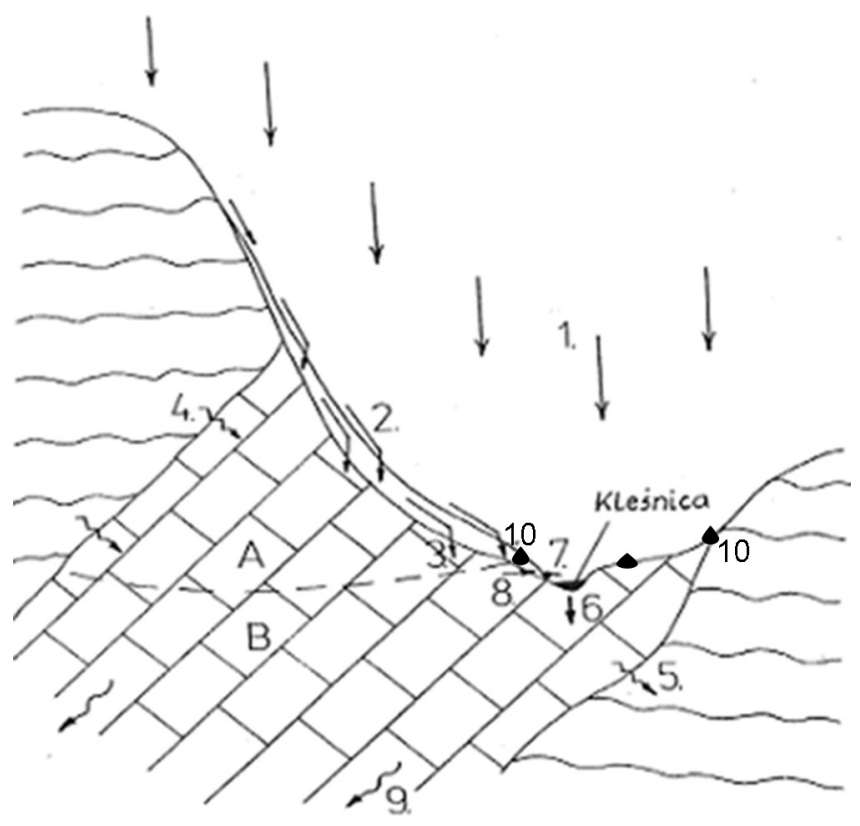

Figure 2. Schematic model of the limestone occurrence in the Klesnica River basin (Bieroński \& Tomaszewski, 1992).

1 - precipitation recharge; 2 - surface runoff recharge; 3 - subsurface runoff recharge; 4 - recharge within massif; 5 - runoff within massif; 6 - Kleśnica River recharge; 7-spring runoff; 8 - subsurface runoff; 9 - runoff outside river basin; 10 - karst spring; $A$ - unsaturated zone; $B$ - saturation zone

intercept rainwater. The studies by Ciężkowski et al. (1986) also confirmed the hypothesis about the escape of water from the Kleśnica River catchment to the neighbouring river catchments, including the Czech Moravia River. In 1970, the measurement of dislocations in the marbles of the Bear Cave and the nearby stone-pit were made. NW-SE, S-N and W-E directions of fissures were determined as well asdislocation zones on the courses of the NW-SE and W-E. In the borehole to a depth of $80 \mathrm{~m}$, near the Kleśnica River, anartesian outflow was observed. The measured discharge of a self-outflow was $6.9 \mathrm{dm}^{3} / \mathrm{s}$ (Kryza, 1988).

\subsection{Methods}

Groundwater renewable resources are usually calculated by the use of methods which allow an assessment of the groundwater runoff. Due to a complicated hydrogeological structure with varying and weak identified hydrogeological parameters, the most useful approaches thus are hydrological methods based on the measurements of the river flow discharge. Rivers are the drainage base of surrounding rock formations.

Groundwater renewable resources identified with the groundwater runoff were determined by hydrology methods based on the hydrometric low flows measurements of the Kleśnica River. The low flows are identified with the river recharge only by groundwater (Dubicki, 2002). In addition, the research area was divided into three river subbasins in order to show the variability of the groundwater runoff. River catchments were designated, each of which represented one of the main types of rocks forming the research area. Therefore, the river subbasin number I form mostly the gneiss, the subbasin number III contains mainly mica schists and paragneisses, while in the catchment number II there are outcrops of marbles. 
Table 2. Surface areas of river subbasins and outcrops of limestones.

\begin{tabular}{c|c|c|c|c}
\hline $\begin{array}{c}\text { Numer } \\
\text { of river } \\
\text { subbasin }\end{array}$ & $\begin{array}{c}\text { Surface } \\
\text { area of } \\
\text { subbasin } \\
{\left[\mathbf{k m}^{2}\right]}\end{array}$ & $\begin{array}{c}\text { Participation } \\
\text { of subbasins } \\
\text { within study } \\
\text { area [\%] }\end{array}$ & $\begin{array}{c}\text { Surface of } \\
\text { limestones } \\
\text { outcrops } \\
{\left[\mathbf{k m}^{2}\right]}\end{array}$ & $\begin{array}{c}\text { Percentage of } \\
\text { imestones outcrops } \\
\text { in surface area of } \\
\text { subbasin [\%] }\end{array}$ \\
\hline I & 5.58 & 37.93 & 0.014 & 0.25 \\
II & 6.55 & 44.53 & 0.466 & 7.11 \\
III & 2.58 & 17.54 & - & - \\
Sum & 14.71 & 100.00 & 0.470 & 3.20 \\
\hline
\end{tabular}

Table 3. Discharge of river flow $\left(\mathrm{dm}^{3} / \mathrm{s}\right)$ in measuring points.

\begin{tabular}{c|c|c|c}
\hline Date & $\begin{array}{c}\text { Hydrometric } \\
\text { profile 1 }\end{array}$ & $\begin{array}{c}\text { Hydrometric } \\
\text { profile 2 }\end{array}$ & $\begin{array}{c}\text { Hydrometric } \\
\text { profile 3 }\end{array}$ \\
\hline 27.08 .2009 & 356.91 & 223.18 & 44.04 \\
\hline 19.09 .2009 & 270.51 & 150.41 & 25.92 \\
\hline 04.10 .2009 & 276.71 & 154.92 & 29.92 \\
\hline 14.02 .2010 & 318.67 & 166.77 & 22.11 \\
\hline $\begin{array}{c}\text { Average discharge of } \\
\text { river flow }\end{array}$ & 305.7 & 174.07 & 30.05 \\
\hline
\end{tabular}

Due to a significant impact of carbonate rocks on the groundwater runoff, the surface area of crystalline limestone outcrops was calculated for all studied subbasins. The surface area of carbonate rock outcrops was $0.47 \mathrm{~km}^{2}$, which represents $3.2 \%$ of the whole catchment areas and $7.1 \%$ of the subbasin II (Table 2). It should be noted that this is only a percentage of marbles outcrops in the study area, but not their actual volume. Hence, their participation in rocks that occurs in the Kleśnica River catchment can be much larger, which would indicate high groundwater modules in relation to the neighbouring catchment, which will also be presented.

Groundwater runoff was calculated on the base of hydrometric measurements of the river flow during low-flow periods. For this purpose, four series of measurements from August 2009 to February 2010 were performed. The studies were carried out in three hydrometric profiles (Figure 3 ). The mmeasurements of a river flow discharge were performed in the following months: August, September, October 2009 and February 2010 (Table 3).

Additionally, a hydrogeological mapping of the Kleśnica River basin was performed in order to determine the spring runoff as part of the dynamic groundwater resources. Mapping was conducted in August-September 2009 and documented 106 natural outflows.

\section{Results and Discussion}

The lowest rates of the river flow discharge were obtained in September 2009 (Table 3). The exception was section 3, where

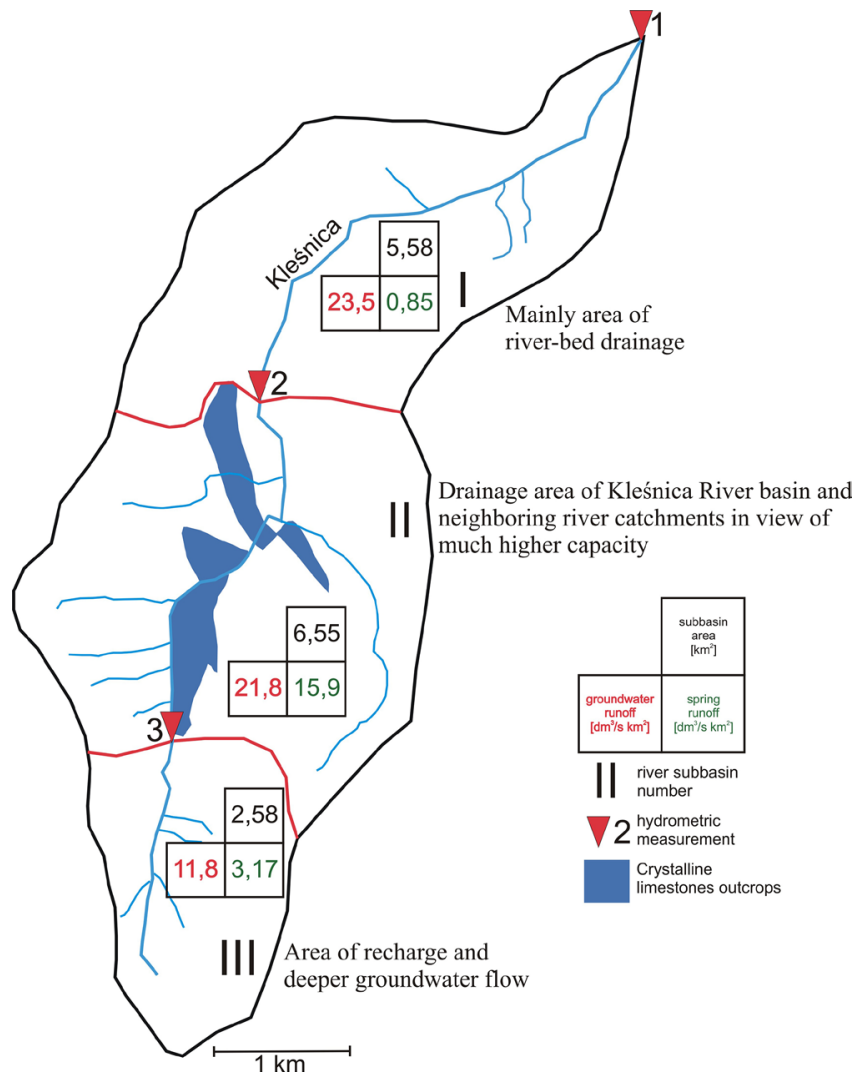

Figure 3. Variability of groundwater runoff in the study area.

the lowest rate was recorded in February 2010. In September 2009 the disappearance of the river flow was observed in the vicinity of the Bear Cave in the Kleśnica River basin. The water disappeared in ponors and, after a stretch of approx. $300 \mathrm{~m}$, reappeared on the surface. The mean groundwater runoff module from four series of measurements amounted to $20.78 \mathrm{dm}^{3} / \mathrm{s}^{*} \mathrm{~km}^{2}$. For each river, subbasins results ranged from 11.83 (subbasin III) to $23.5 \mathrm{dm}^{3} / \mathrm{s}^{*} \mathrm{~km}^{2}$ (subbasin I) (Figure 3). The groundwater runoff module in the catchment II, which contained, by far, the largest area of crystalline limestone outcrops, was slightly lower than the result achieved for the subbasin I. Probably, a part of water drained within the subbasin II through the deeper circulation occurred in subbasin I.

The calculated groundwater runoff parameters are very high. According to Krasny \& Kneżek's classification (1977), almost all the results obtained are within the last VIII group (Table 4), typical for the river basins of an extremely high groundwater runoff moduls (more than $10 \mathrm{dm}^{3} / \mathrm{s}^{*} \mathrm{~km}^{2}$. Only one of the results, measured in February 2010 in the subbasin III $\left(8.58 \mathrm{dm}^{3} / \mathrm{s}^{*} \mathrm{~km}^{2}\right)$, was classified as Class VII, which is the river basin of a very high groundwater runoff modulus (7-10 $\mathrm{dm}^{3} / \mathrm{s}^{*} \mathrm{~km}^{2}$.

In order to determine the groundwater runoff directly derived from springs, the hydrogeological mapping was performed. The 
Table 4. Numerical characteristics of groundwater runoff $\left(\mathrm{dm}^{3} / \mathrm{s} \mathrm{km}^{2}\right)$ in studied subbasins.

\begin{tabular}{c|c|c|c|c}
\hline Date & $\boldsymbol{\Sigma}(\mathbf{I}, \mathbf{I I}, \mathrm{III})$ & $\mathbf{I}$ & II & III \\
\hline 27.08 .2009 & 24,27 & 23,97 & 27,35 & 17,08 \\
\hline 19.09 .2009 & 18,39 & 21,15 & 18,44 & 10,06 \\
\hline 04.10 .2009 & 18,82 & 21,83 & 19,09 & 11,6 \\
\hline 14.02 .2010 & 21,67 & 27,05 & 22,24 & 8,58 \\
\hline $\begin{array}{c}\text { Average modulus of } \\
\text { groundwater runoff }\end{array}$ & 20,79 & 23,5 & 21,78 & 11,83 \\
\hline
\end{tabular}

Table 5. Classification of mapped springs discharge (by Meinzer).

\begin{tabular}{|c|c|c|c|c|}
\hline $\begin{array}{l}\text { Spring discharge } \\
\text { class }\left[\mathrm{dm}^{3} / \mathrm{s}\right]\end{array}$ & $\begin{array}{l}\text { Quantity } \\
\text { of spring }\end{array}$ & $\begin{array}{c}\text { Percentage } \\
{[\%]}\end{array}$ & $\begin{array}{c}\text { Total spring } \\
\text { discharge }\left[\mathrm{dm}^{3} / \mathrm{s}\right]\end{array}$ & $\begin{array}{c}\text { Percentage } \\
\text { [\%] }\end{array}$ \\
\hline IV (10-100) & 2 & 1.9 & 68.9 & 58.7 \\
\hline$V(1-10)$ & 10 & 9.4 & 28.03 & 23.9 \\
\hline VI (0.1-1) & 66 & 62.3 & 18.9 & 16.1 \\
\hline VII (0.01-0.1) & 27 & 25.5 & 1.55 & 1.3 \\
\hline VIII $(<0.01)$ & 1 & 0.9 & - & - \\
\hline Total & 106 & 100 & 117.38 & 100 \\
\hline
\end{tabular}

Table 6. Spring and river-bed drainage.

\begin{tabular}{c|c|c|c|c|c}
\hline $\begin{array}{c}\text { Numer } \\
\text { of river } \\
\text { subbasin }\end{array}$ & $\begin{array}{c}\text { Total spring } \\
\text { discharge } \\
{\left[\mathbf{d m}^{3} / \mathbf{s}\right]}\end{array}$ & $\begin{array}{c}\text { Modulus } \\
\text { of spring } \\
\text { runoff } \\
{\left[\mathbf{d m}^{3} / \mathbf{s}^{*} \mathbf{k m}^{2}\right]}\end{array}$ & $\begin{array}{c}\text { Modulus of } \\
\text { groundwater } \\
\text { runoff } \\
{\left[\mathbf{d m}^{3} / \mathbf{s}^{*} \mathbf{k m}^{2}\right]}\end{array}$ & Hs/Hg·100\% & $\mathbf{a}_{\mathbf{z}}$ \\
\hline I & 4.75 & 0.85 & 23.5 & 3.6 & 0.04 \\
\hline II & 104.44 & 15.9 & 21.78 & 73.2 & 0.73 \\
\hline III & 8.19 & 3.17 & 11.83 & 26.8 & 0.27 \\
\hline $\begin{array}{c}\text { Kleśnica } \\
\text { river } \\
\text { basin }\end{array}$ & 117.38 & 7.98 & 20.79 & 38.4 & 0.38 \\
\hline
\end{tabular}

$\mathrm{Hs}$ - spring runoff; $\mathrm{Hg}$ - groundwater runoff; $\mathrm{a}_{\mathrm{z}}$ - spring and groundwater runoff ratio;

springs density index in the research area (the number of springs per $1 \mathrm{~km}^{2}$ of surface are), amounted to 7.2 , which is a high score. For individual sub-catchments, it varied from 3.4 (subbasin I) to 10.5 (subbasin III). According to Meinzer classification, all mapped springs were included in classes IV to VIII. In the outflow from the abandoned quarry of marble, the highest value of discharge $\left(52.9 \mathrm{dm}^{3} / \mathrm{s}\right)$ was recorded. Although only two outflows were classified in class IV, which represents only $1.9 \%$ of all outflows, their total discharge amounted to $68.9 \mathrm{dm}^{3} / \mathrm{s}$, which makes up $58.7 \%$ of the total discharge of all springs. Both outflows drained carbonate rocks. However, the largest spring discharges belong to $\mathrm{VI}^{\text {th }}$ class (Table 5).

The spring runoff does not reflect the total groundwater runoff from the Kleśnica River basin, because its important element is the direct inflow of groundwater into the main stream and its

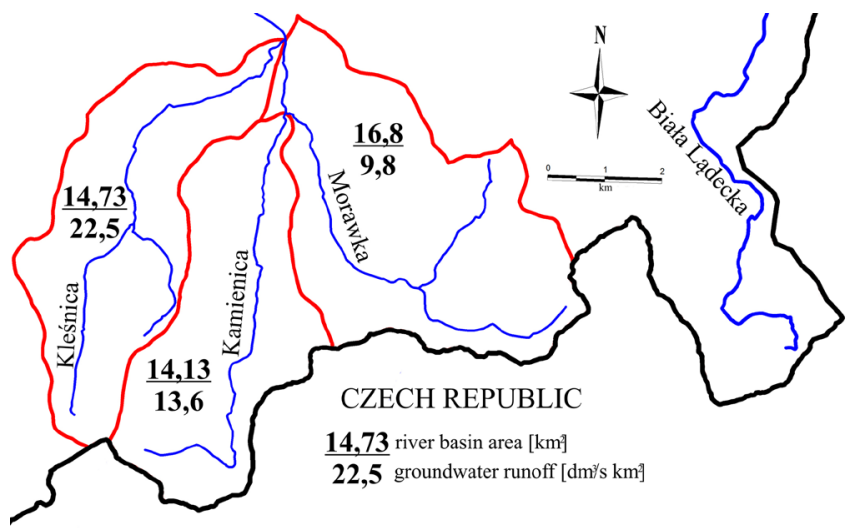

Figure 4. Mean groundwater runoff modulus in study area and neighbouring river catchments (based on Kryza, 1988).

tributaries (Kryza, 1988). The ratio of the spring and river bed drainage represents the drainage coefficient of the river catchment by springs $a_{z^{\prime}}$ which is a quotient of all spring discharges in the basin to the total flow in a stream or streams which discharge water outside the river catchment area (Kryza, 1988). The values of the spring and river bed drainage ratio, calculated for sub-catchments in 2009 ranged from 0.04 (I) to 0.73 (II) with a mean value of 0.38 (Table 6). The lowest values are related to the subbasin I, due to a small number of springs recorded in the river basin and their limited capacity. A relatively low result was obtained also in the upper part of the catchment (III). The deepest river beds drained effectively well permeable rubbles and, partially, also massif rock. A very high rate was observed in the catchment II, where surface water escaped to the karst systems and highly efficient karst springs, draining water from the abandoned stone pits of marble and significantly increasing the total discharge of outflows.

The study area is distinguished by a higher groundwater runoff compared the neighbouring river catchments (Figure 4). The Kamienica and Morawka River catchments have similar geological structure, morphology and climatic conditions, but do not contain so clearly outlined outcrops of carbonate rocks. All the compared basins are located in the central part of the Śnieznik Massif, on its northern slopes. The total surface area of the described basins equals $45.64 \mathrm{~km}^{2}$ (Morawka basin $16.8 \mathrm{~km}^{2}$, Kamienica basin $14.13 \mathrm{~km}^{2}$, Kleśnica basin $14.71 \mathrm{~km}^{2}$ ). For the compilation of the groundwater renewable resources in the above river catchments, groundwater runoff modules were used, calculated on the basis of the discharge outflow measurements in July 1974 (Kryza, 1988). The highest runoff $\left(22.5 \mathrm{dm}^{3} / \mathrm{s}^{*} \mathrm{~km}^{2}\right)$ was estimated in the Kleśnica River basin. The Kamienica River catchment achieved the mean value of $13.6 \mathrm{dm}^{3} / \mathrm{s}^{*} \mathrm{~km}^{2}$, while the lowest value was recorded for the Morawka River basin of $9.8 \mathrm{dm}^{3} / \mathrm{s}^{*} \mathrm{~km}^{2}$ (Figure 4). The results obtained for the Kleśnica River basin are significantly higher than the neighbouring catchments. The Kamienica River 
catchment achieved the result approx. $60 \%$ and the Morawka River basin over 2 times lower compared to that of Kleśnica River. Although these three catchments are located in the immediate vicinity and occupy areas with similar geological structure and climate, they have much lower dynamic groundwater resources than the Kleśnica River basin. Therefore, one could suggest that crystalline limestones have excellent hydrogeological conditions for the collection and circulation of groundwater. The mean groundwater runoff calculated for the whole study area (Figure 4) equals $15.3 \mathrm{dm}^{3} / \mathrm{s}^{*} \mathrm{~km}^{2}$ (482.5 mm). Similar renewable groundwater resources were presented by Olichwer \& Tarka (2005). As a result of their calculations, the discussed area was assigned to the catchments group characterized by the highest renewable groundawater resources of the Kłodzko Land region where the renewable resources exceed $400 \mathrm{~mm}$.

\section{Conclusions}

The studies of water in karst systems show that they are an interesting subject of research because of their close relationship with the waters of the surrounding crystalline formations and as capacious groundwater reservoirs. The Kleśnica River basin is a complicated hydrogeological structure characterized by the occurrence of extensive karst formations represented by crystalline limestones. The study area has a large number of natural outflows. The springs' density index equals 7.2 , a spring runoff module is $7.98 \mathrm{dm}^{3} / \mathrm{s}^{*} \mathrm{~km}^{2}$, which constitutes approx. $40 \%$ of the river bed drainage. The most efficient springs were found within the crystalline limestones. The groundwater runoff module, based on the hydrometric measurements of Kleśnica's low-flow, ranged from 18.39 to $24.27 \mathrm{dm}^{3} / \mathrm{s}^{*} \mathrm{~km}^{2}$, with a mean value of $20.79 \mathrm{dm}^{3} / \mathrm{s}^{*} \mathrm{~km}^{2}$. The research area belongs to the catchment area with extremely high runoff modulus of groundwater. This module, located in the central part of the study area, is built from crystalline limestones of a much higher dimensions than in the neighbouring sub-basins.

Similar results were observed in the Piotrkówka River catchment, located within the metamorphic of Krowarki (Metamorphic of Ladek-Śnieżnik). In the western part of the catchment, within the paragneisses and mica schists, the crystalline limestone lenses were observed. The carbonate rocks occurring in the described area are characterized by superior hydrogeological properties, when compared to the mica schists and gneisses. The crystalline limestones have a fairly substantial porosity in a well developed network of fractures and karst systems. The result of this is an increased groundwater runoff $\left(24.17 \mathrm{dm}^{3} / \mathrm{s}^{*} \mathrm{~km}^{2}\right)$ and spring runoff $\left(12.3 \mathrm{dm}^{3} / \mathrm{s}^{*} \mathrm{~km}^{2}\right)$, in relation to the river subbasins, which only contain schists and gneiss $\left(\mathrm{Hg}=3.5 \mathrm{dm}^{3} / \mathrm{s}^{*} \mathrm{~km}^{2}, \mathrm{Hs}=\right.$ $1.07 \mathrm{dm}^{3} / \mathrm{s}^{*} \mathrm{~km}^{2}$ ) (Olichwer, 2002).

\section{References}

[1] Bieroński J. 1989. Hydrology of Kleśnica River Catchment. [In:] Jahn A., Kozłowski S., Wiszniowska T. (eds.) The Bear Cave in Kletno, 202220, Research and sharing, Ossolineum, Wroclaw, (in polish).

[2] Bieroński J., Tomaszewski J.T. 1992. Conditions of the water circulation in the inserts of metamorphic marble of Sudety Mts. Conference Proceedings Hydrogeological Problems of Southwestern Poland, Wroclaw, 7-13 (in polish).

[3] Bocheńska T., Dowgiałło J., Kleczkowski A., Macioszczyk A., Różkowski A. 2002 a. Hydrogeological Dictionary, Polish Geological Institute Publisher, Warsaw, (in polish).

[4] Bocheńska T., Marszałek H., Wąsik M. 2002 b. Groundwater reservoirs in karst areas of the crystalline Sudeten. Acta Universitatis Wratislaviensis No 2460. University of Wrocław, Wroclaw, 1-64 (in polish).

[5] Ciężkowski W., Pulina M., Řehak J. 1986. The latest Polish-Czech research in the Śnieżnik Massif. Science Works of Geotechnical. Inst. of Technical University of Wrocław. 49, Conferences Series 21, (in polish).

[6] Ciężkowski W. 1989. Hydrogeological Research of Śnieżnik Massif Karst Area. [In:] Jahn A., Kozłowski S., Wiszniowska T. (eds.) The Bear Cave in Kletno, 180-201, Research and sharing, Ossolineum, Wroclaw (in polish).

[7] Ciężkowski W., Kryza H., Kryza J., Pulina M., Řehak J., Staśko S., Tarka R. 1997. Groundwater and the Influence of Anthropogenic Factors on Their Resources and Quality. [In:] Jahn A., Kozłowski S., Pulina M. (eds.) Śnieżnik Massif, Changes in the Natural Environment, 147-169. PAE, Warsaw, (in polish).

[8] Don J., Dumicz M., Wojciechowska I., Żelaźniewicz A. 1990. Lithology and tectonics of the Orlica-Śnieżnik Dome, Sudetes-Recent state of knowledge. Neues Jahrbuch für Geologie und Paläontologie, Abhandlungen, 197, 159-188.

[9] Dubicki A. 2002. Water Resources in the Upper and Middle Odra Basin in Drought Conditions, Atlases and monographs, 1-107, IMGW Publisher, Warsaw, (in polish).

[10] Gilli E., Mangan C., Mudry J., 2013. Hydrogeology: Objectives, Methods, Applications. Translated from the French by Chloe Fandel. CRC Press, Editor: Taylor and Francis Group.

[11] Krasny J., Kneźek M. 1977. Regional estimate of groundwater runoff from fissured rocks on using transmissivity coefficient and geomorphologic characteristics. Journal of Hydrological Sciences 4, 2: 149-159.

[12] Kryza H., Kozłowski J. 1998. The groundwater runoff in the Kleśnica river basin in the Śnieżnik Massif, Geological-Mineralogical Works LXVII, 85-89, Wrocław, (in polish).

[13] Kryza H. 1988. The forming of groundwater runoff in mountainous river catchments of Śnieżnik Massif, Geological—Mineralogical Works, t.XI.2, Wrocław University Publisher, Wrocław, (in polish).

[14] Małecka D. 1997. Springs of the Tatra Massif. Acta Universitatis Lodziensis, Folia Geographica Physica, 2: 9-26, (in polish).

[15] Motyka J. 1998. A conceptual model of hydraulic networks in carbonate rocks, illustrated by examples from Poland. Hydrogeol J., 6 : 469-482.

[16] Mroczkowska B. 1983. The chemistry of groundwater of Śnieżnik Massif. Conference Proceedings, Modern Problems of Hydrogeology. Lądek Zdrój, 13-16 October 1982, Wrocław University Publisher, Wroclaw, 271-284, (in polish). 
[17] Olichwer T. 2002. An outline of the hydrogeological conditions with particular emphasis on the groundwater runoff in Krowiarki Metamorphic (Lądek-Śnieżnik Massif). Acta Universitatis Wratislaviensis, No. 2370, Geol.-Mineral Works. LXXII, Wrocław University Publisher, Wroclaw, 51-61 (in polish).

[18] Olichwer T., Tarka R. 2005. Are Sudety Mts. Waterless Area on Kłodzko Land Example, Modern Problems of Hydrogeology XII, 531-538, Nicolaus Copernicus University Publisher, Toruń, (in polish).
[19] Pulina M. 1970. Preliminary research results of the geographical environment of Bear Cave. Acta Universitatis Wratislaviensis 127, Geographic Studies XIV, Wrocław, 5-37, (in polish).

[20] Schmidt W., Lloyd J.M., Collier C. 1998. The Wakulla Springs Woodville Karst Plain Symposium, Transactions October 9, 1998. Published by the Florida Geological Survey, Tallahassee, Florida. Special Publication No. 46, 1-193.

[21] Tarka R. 1997. The recharge of groundwater in crystalline mountain ranges on the example of research in the Śnieżnik Massif. Geological-Mineralogical Works LVI, 1-66, University of Wroclaw, (in polish). 